\title{
KOMPLEX CSOMÓPONTOK HŐENERGETIKAI ELEMZÉSE EGY ENERGIAHATÉKONY ISKOLAÉPÜLETNÉL
}

\section{THERMAL BEHAVIOUR ANALYSIS OF COMPLEX JOINTS FOR AN ENERGY EFFICIENT SCHOOL BUILDING}

\author{
Karda Szilárd, ${ }^{1}$ Nagy-György Tamás, ${ }^{2}$ Boros József ${ }^{3}$ \\ Temesvári Müszaki Egyetem, Építőmérnöki Kar. Temesvár, Románia \\ ${ }^{1}$ szilard.karda@student.upt.ro \\ 2 tamas.nagy-gyorgy@upt.ro \\ 3 iosif.boros@student.upt.ro
}

\begin{abstract}
Energy-efficient buildings have received increasing attention in recent times as they represent a direction that promotes the objectives of a sustainable, competitive and decarbonized energy policy. In order to meet the minimum requirements of the nearly zero-energy buildings (nZEB) the thermal characteristics of the envelope play an important role. The aim of the paper is to present and analyse the thermal behaviour of complex joints for an energy efficient school building, for which the formation of thermal bridges has been reduced by applying improved geometrical and technological solutions. Since most of the thermal bridge catalogues did not provide updated details for the studied joints, numerical calculations, as two-dimensional finite elements thermal simulations, were performed to determine thermal transmittance coefficients and the U-value.
\end{abstract}

Keywords: energy efficiency, thermal bridges, complex joints, thermal transmittance coefficient.

\section{Összefoglalás}

Az energiahatékony épületek fokozott figyelmet élveznek az utóbbi időben, mivel olyan irányt képviselnek, ami elősegíti a fenntartható, versenyképes és dekarbonizált energiapolitika célkitűzéseit. Annak érdekében, hogy az épületek megfeleljenek a közel nulla energiaigényü létesítmények minimumkövetelményeinek, fontos szerepet kapnak a térelhatároló elemek hőtechnikai jellemzői. A dolgozat célja, hogy bemutassa és elemezze egy energiahatékony iskolaépület azon komplex csomópontok hőenergetikai viselkedését, amelyek esetében különböző geometriai és technológiai megoldásokat alkalmazva csökkent a hőhidak kialakulásának lehetősége. Mivel a jelenlegi hőhídkatalógusok túlnyomó része nem szolgált naprakész adatokkal a tanulmányozott csomópontok számára, numerikus számításokra és kétdimenziós végeselem-szimulációra volt szükség a hőátbocsátási tényezők meghatározására.

Kulcsszavak: energiahatékonyság, hőhidak, komplex csomópontok, hőátbocsátási tényező.

\section{Bevezetés}

Az energiafogyasztás kérdése fokozott figyelmet élvezett az utóbbi évtizedekben az Európai Unió számára. Az Unió vezetői 2007-ben azt a célt tűzték ki, hogy 2020-ig 20\%-kal csökkentik az EU éves energiaszükségletét, és ezt a cselekvési irányvonalat folytatva a tagállamok 2030-ra 32,5\%-os visszaesést érjenek el. Az energiahatékonysági intézkedések nem csupán az üvegházhatású gázkibocsátások csökkenésének, illetve a fenntartható energiaellátás megvalósításának eszközei, hanem az államok versenyképességének fokozásában is fontos szerepet kapnak [1], ezért ezen cselekvési terv stratégia prioritás az Európai Unió számá- 
ra. Jelenleg az épületek az energia-végfogyasztás 40\%-áért és a széndioxid-kibocsátás 36\%-áért felelősek, ezért az új és meglévő épületek energiateljesítményének növelése érdekében a 2010/31 EU-irányelv számos előírást tartalmaz, melyek közül fontos kiemelni a közel nulla energiaigényü épületeket (a továbbiakban KNE).

A KNE-épületek magas energiahatékonysággal rendelkező létesítmények, melyekben a felhasznált közel nulla vagy nagyon alacsony mennyiségü energia legalább 30\%-a megújuló forrásokból kell származzon [2]. A hatályos jogi keretek alapvető követelményei közé tartozik, hogy Romániában minden új épület, melynek használatbavétele 2020. december 31. után kiállított építkezési engedély alapján történik, közel nulla energiaigényü épület kell legyen [3].

Romániában az épületek átlagos primer energiafogyasztása megközelítőleg $250 \mathrm{kWh} / \mathrm{m}^{2}$ év, ami 25\%-kal nagyobb az EU középértékéhez képes, köszönhetően az épületek elavult és alacsony hatásfokának. A KNE-épületek számára meghatározott primerenergia-fogyasztás $100-185$ kWh/m²év közötti értéket vehet fel. Az energiahatékonyságot jelentős mértékben befolyásolják az épületelemek hőtechnikai jellemzői, az épület elhelyezése és tájolása, a fütési és a légkondicionáló rendszerek, a természetes és gépi szellőztetés, a beépített világítóberendezések, a passzív napenergia-hasznosító rendszerek és az árnyékolás, a beltéri klimatikus körülmények, illetve a belső hőterhelések [4].

Jelen dolgozat egy oktatási épület térelhatároló szerkezetének csomópontjait vizsgálja, amelyek megoldásként szolgálhatnak a hőhidak csökkentése érdekében. Mivel az épületek energiafogyasztásának több mint 50\%-át a fütéshez szükséges energia teszi ki, az energiahatékonyság növelése érdekében ez az arány jelentősen visszaeshet, ha megfelelő hőszigeteléssel rendelkeznek az épülethatároló szerkezetek és a lehető legkevesebb olyan zóna létezik, ahol hőhidak alakulhatnak ki. Nagyobb figyelmet fektetve a csomópontoknál lehetséges hőhidakra, optimalizálni lehet a szerkezetek hőátbocsátási tényezőit és a fajlagos hőveszteséget.

\section{Közel nulla energiaigényü iskolaépület}

A nagyszalontai Arany János Elméleti Líceum új épületszárnya 2017-ben került átadásra és Románia első közel nulla energiaigényű oktatási épületének számít, amely megfelel a passzív házak által előírt követelményeknek is. A $3496 \mathrm{~m}^{2}$ hasznos alapterülettel rendelkező épület vasbe- ton teherhordó keretszerkezete egy gerendarács alapon fekszik. A szerelő aljzatbeton alatt $20 \mathrm{~cm}$ XPS hőszigetelés található, az oldalsó térelhatároló elemeket $25 \mathrm{~cm}$ vastag pórusbeton falazat és $15 \mathrm{~cm}$ kőzetgyapot alkotja, a nyílászárók 6 kamrás műanyag ablakszerkezetből és 3 rétegü üvegszerkezetből állnak, a fütetlen padlás alatti vasbeton födém hőszigetelése pedig $25 \mathrm{~cm}$ kőzetgyapottal valósult meg.

A csomópontok vizsgálata stacioner állapotban történik. A numerikus szimulációhoz szükséges meghatározni a szerkezet geometriáját, a geometriát alkotó anyagok hőkapacitását, hővezetési tényezőjét, testsűrűségét, illetve a külső és belső peremfeltételeket [5].

A külső hőmérséklet méretezési értéke az ország éghajlati övezete függvényében határozható meg. Nagyszalonta a második éghajlati övezetben helyezkedik el, tehát a méretezési külső hőmérséklet $-15^{\circ} \mathrm{C}$. Az épület belső hőmérséklete $+18^{\circ} \mathrm{C}$, melyet a helyiségek rendeltetése számára előírt hőmérsékletek súlyozott átlagából lehet kiszámítani. A padlástér hőmérsékletét a méretezési külső hőmérséklet, az előírt belső hőmérséklet, illetve a térelhatároló elemek eredő hővezetési ellenállása határozza meg. Az így kapott helyiség-hőmérséklet a fütetlen térben $-11,35^{\circ} \mathrm{C}$.

A külső légköri állapot statisztikai átlaga szerint a páratartalom 70\%-os, míg a belső léghőmérséklethez 60\%-os páratartalom van meghatározva. A számításoknál alkalmazott külső és belső oldali felületi hőátadási ellenállás sorrendben $25 \mathrm{~W} / \mathrm{m}^{2} \mathrm{~K}$ és $8 \mathrm{~W} / \mathrm{m}^{2} \mathrm{~K}$.

\section{A hőhidak és hőátbocsátási tényezők számítása}

A hőátbocsátási tényező, vagyis az $U$ érték egy felület hőszigetelésének a jellemzője, amely kifejezi, hogy egy adott szerkezet egységnyi területén, egységnyi hőmérséklet hatására mekkora hőáram halad át. A térelhatároló szerkezet tényleges hőátbocsátását azonban különféle ismétlődő vonalmenti, illetve pontszerü inhomogenitások befolyásolják [6], ezért a rétegtervi $U^{\prime}$ érték az alábbi képlet alapján számítható ki (1):

$$
U^{\prime}=\frac{1}{R_{s i}+\sum_{i} \frac{d_{i}}{\lambda_{i}}+R_{s e}}+\frac{\sum(\psi \cdot l)}{A}+\frac{\sum \chi}{A}\left[\frac{W}{m^{2} K}\right]
$$

ahol

- $R_{s e}$ és $R_{s i} \quad$ - a külső és belső oldali felületi hőátadási ellenállás $\left[\mathrm{m}^{2} \mathrm{~K} / \mathrm{W}\right]$;

$-d_{i}-$ a szerkezeti rétegrend vastagsága [m]; 
$-\lambda_{i}$ - a szerkezeti rétegrend hővezetési tényezője [W/mK];

- $l$ - a vonalmenti hőhíd hossza [m];

- $\psi$ - a hőhíd vonalmenti hőátbocsátási tényezője [W/mk];

- A - a határoló elem felülete $\left[\mathrm{m}^{2}\right]$;

- $\chi$ - a hőhíd pontszerü hőátbocsátási tényezője.

A hőhidak a határolószerkezetek azon zónáin találhatóak, ahol többdimenziós hőáramlás és hőmérséklet-eloszlás alakul ki, köszönhetően az eltérő vastagságú és hővezetésủ rétegeknek, illetve a különböző külső és belső dimenzióknak [7]. A hőhidak a vonalmenti és pontszerü hőveszteségek mellett hőkomfort, illetve épület-szerkezettani problémákat okozhatnak, ezért a redukálásuk esszenciális fontosságú. A hőhidakat mértékét a vonalmenti (2), illetve a pontszerü hőátbocsátási tényezők (3) határozzák meg.

$$
\begin{aligned}
& \psi=\frac{L_{2 D}-\sum U \cdot A}{l}[W / m K] \\
& \chi=\frac{\Phi}{\Delta T}-U \cdot A[W / K]
\end{aligned}
$$

ahol

- $L_{2 D}$ - hőhídtényező a kétdimenziós számításokból [W/mK];

- U - a kezdeti hőátbocsátási tényező [W/ $\left./ \mathrm{m}^{2} \mathrm{~K}\right]$;

- $\Phi$ - a pontban kialakult hőáram [W];

- $\Delta T$ - a kültéri és beltéri hőmérséklet-különbség $\left[{ }^{\circ} \mathrm{C}\right]$.

A csomópontok hőtechnikai szimulációja a HTflux végeselem-programmal történt [8], amely során meghatározásra kerültek a hőhídtényezők, a hőáramok, a hőáramsűrűségek, illetve a hőmérséklet-eloszlás.

\subsection{Padlásfödém}

Az épület fütött és fütetlen terét elválasztó padlásfödém hőszigetelő szerkezete egy 15, illetve $10 \mathrm{~cm}$ vastag kőzetgyapot lemezből áll, melynek a hőátbocsátási tényezője a rétegrendek szerint $0,150 \mathrm{~W} / \mathrm{m}^{2} \mathrm{~K}$ (1. táblázat). A fütetlen légteret egy

1. táblázat. A padlásfödém hőátbocsátási tényezője

\begin{tabular}{|l|c|c|}
\hline \multicolumn{1}{|c|}{ Rétegsorrend } & $\begin{array}{c}\lambda \\
\text { [W/mK] }\end{array}$ & $\begin{array}{c}\text { Vastagság } \\
\text { [cm] }\end{array}$ \\
\hline Kőzetgyapot & 0,039 & 25 \\
\hline Párafékező fólia & 0,290 & 0,2 \\
\hline Vasbeton födém & 1,740 & 13 \\
\hline Beltéri vakolat & 0,930 & 1,5 \\
\hline \multicolumn{2}{|c|}{ U-érték $\left[\mathrm{W} / \mathrm{m}^{2} \mathrm{~K}\right]$} \\
\hline
\end{tabular}

nyeregtető zárja be, melynek a tartóelemei a vasbeton gerendás födémen támaszkodnak, ezáltal a székoszlop és papucsfa zónájában változik a hőszigetelés vastagsága, illetve a folytonossága, ezáltal módosítva az egységnyi felületre eső hőáramot.

A székoszlopoknál kialakuló pontszerü és vonalmenti hőhidak redukálása érdekében a papucsfa sávjában megmaradt a hőszigetelés második, $10 \mathrm{~cm}$ vastag kőzetgyapot lemeze, a székoszlop pedig egy $15 \mathrm{~cm}$ vastag bazalt paplannal lett betakarva a fogópár aljáig (1. ábra).

A papucsfák rögzítéséhez használt menetes szárak esetében pontszerű hőhidak alakulnak ki, melyeknek a számbavétele egy precízebb hőátbocsátási tényezőhöz vezet.

A végeselem-modellezés során a papucsfák sávjában a hőáram értéke $4,758 \mathrm{~W} / \mathrm{m}$, a kültéri és beltéri hőmérséklet-különbség $29,37^{\circ} \mathrm{C}$. Meghatározva a hőhídtényezőt $\left(L_{2 D}\right)$, a papucsfa alatti vonalmenti hőátbocsátási tényező értéke $0,017 \mathrm{~W} / \mathrm{mK}$ (2. ábra).

A passzívházak tervezésénél azokat a csomópontokat nevezik „hőhídmentes kialakításnak”, amelyeknél a vonalmenti hőátbocsátási tényező értéke 0,01 W/mK alatt van [9].

A székoszlopok alsó pontjában keletkezett 0,744 W hőáram 0,0219 W/K pontszerű hőátbocsátási tényezőt határoz meg. A menetes szárak nincsenek közvetlen kapcsolatban a padlástér alacsonyabb hőmérsékletével, az általuk meghatározott pontszerű hőhíd $\chi$ értéke elenyésző, 0,0006 W/K. A székoszlopok hőszigetelése hiányá-

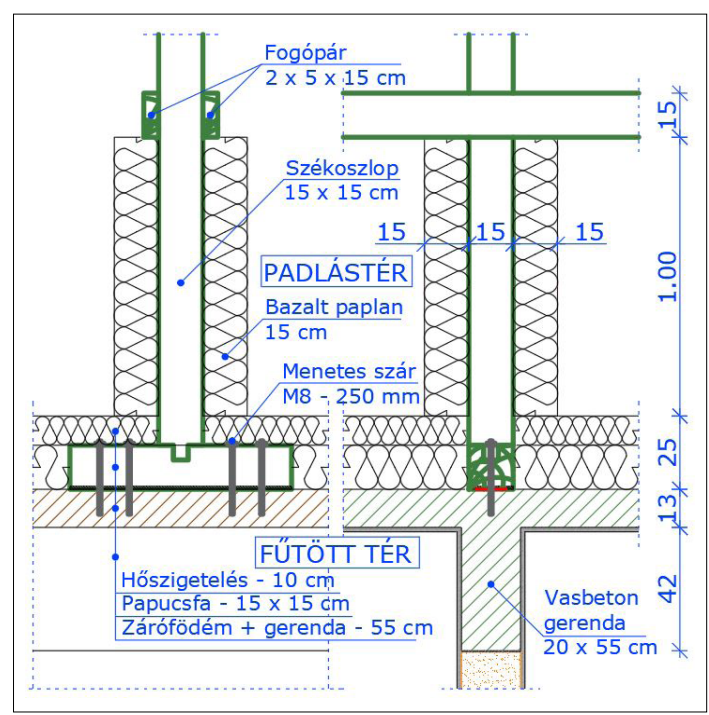

1. ábra. A székoszlopok hőszigetelése 


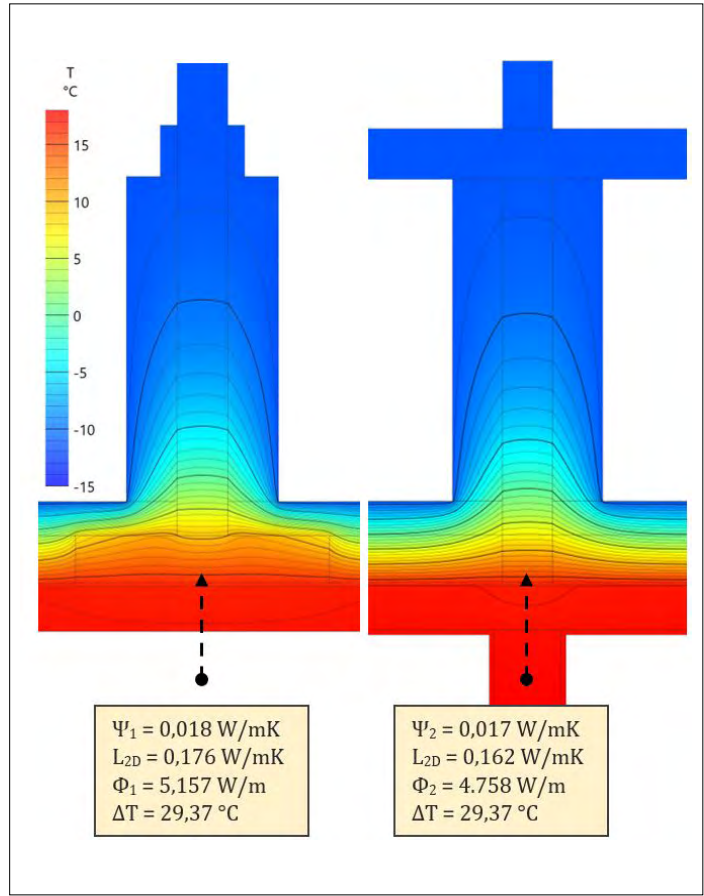

2. ábra. A hőszigetelt székoszlopok hőmérsékleteloszlása és $\Psi$ értékei

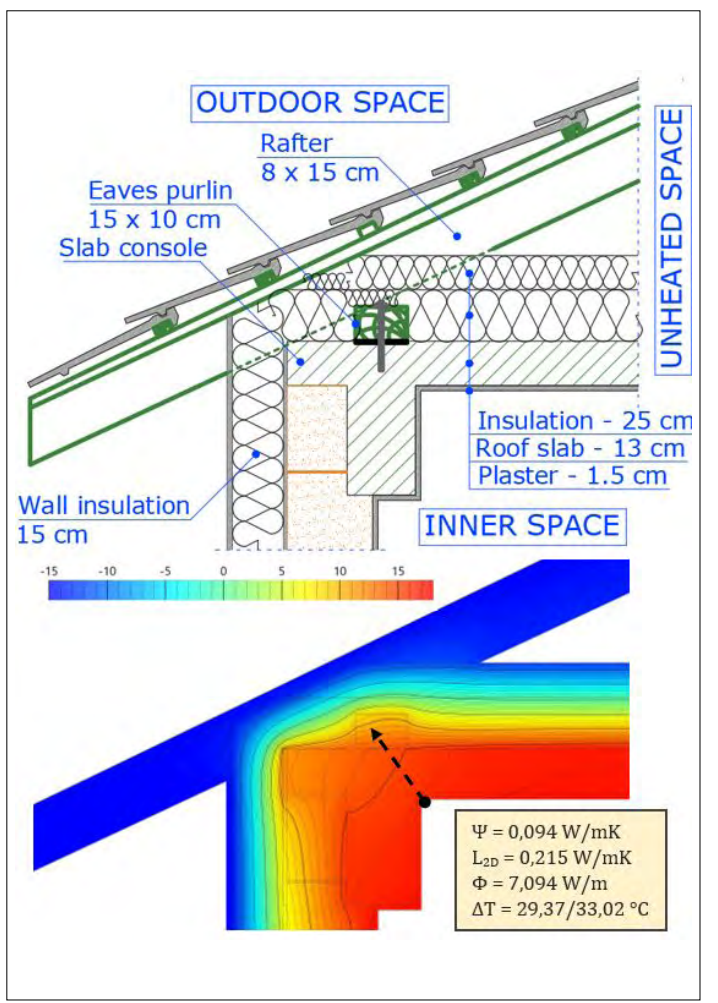

3. ábra. A talpszelemen hőszigetelése és $\Psi$ értéke ban a $\psi$ és $\chi$ jelentősen megnőne $0,075 \mathrm{~W} / \mathrm{mK}$, illetve $0,0314 \mathrm{~W} / \mathrm{K}$-re.

A hőhidak javítása érdekében a talpszelement betakaró hőszigetelő réteg a szarufák között a zárófödém végéig tart (3. ábra), ahol csatlakozik a külső homlokzati szigeteléssel, megtartva ezáltal a termikus burok folytonosságát.

Azáltal, hogy a talpszelemen nincs közvetlen kapcsolatban a külső alacsony hőmérséklettel, a kezdeti vonalmenti hődíd 0,183 W/mK értéke helyett a kapott $\Psi$ érték 0,094 W/mK, ami így is fokozottabb hőveszteséggel jár a gerendafödém belső sarkánál, de a szarufák és a szerkezeti elemek pozíciója nem tett lehetővé kedvezőbb lehetőséget a hőhíd csökkentésére. A horganyzott menetes rudak által létrejött pontszerű hőhidak együtthatói 0,0006 W/K darabonként.

Az épület keleti és északi oldalán található szomszédos házak következtében a tüzfalak egészen a nyeregtető csúcsáig tartanak, ezért a zárófödém két oldalsó sávjánál kialakuló lineáris hőhidak alakulnak ki. Ebből kifolyólag a padlás szintjén a külső fal homlokzati hőszigetelése követi az alsó szintek vastagságát, illetve a zárófödém és a fütetlen tér találkozásánál 2,00 méter magasságáig a fal belső oldalán többlet-hőszigetelés található (4. ábra). A külső homlokzati falnak a padlástér alatti, illetve feletti rétegrendje és hőátbocsátási tényezője a 2. táblázatban található.

A homlokzati falak hőszigetelésénél használt csavaros műanyag tiplik acél beütőszegei pontszerű hőhidakat hoznak létre a hőszigetelés, illetve a tartóelemek vastagságában. Az épületnél

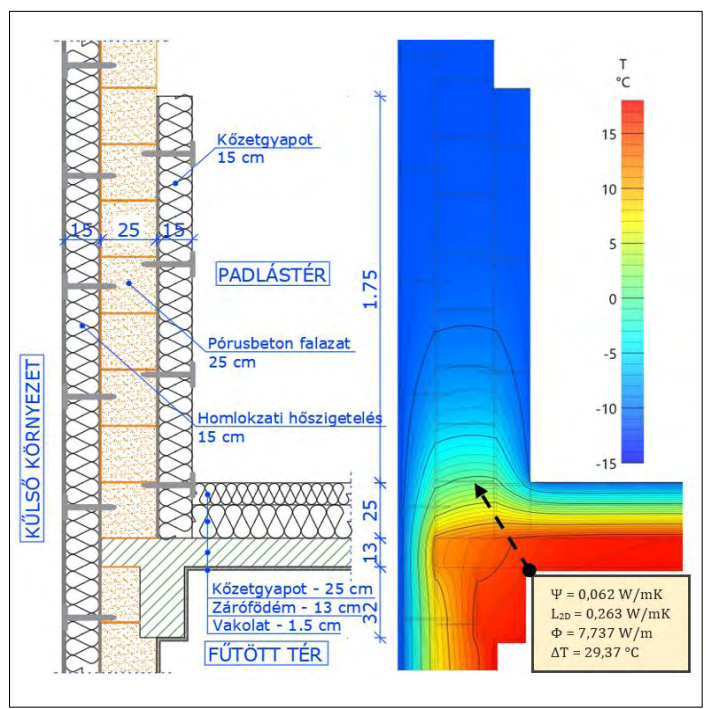

4. ábra. A tüzfal-zárófödém csomópont 
2. táblázat. A külső falazat és a padlástéri tüzfal höátbocsátási tényezője

\begin{tabular}{|l|c|c|}
\hline \multicolumn{1}{|c|}{ Rétegsorrend } & $\begin{array}{c}\lambda \\
\text { [W/mK] }\end{array}$ & $\begin{array}{c}\text { Vastagság } \\
\text { [cm] }\end{array}$ \\
\hline Beltéri vakolat & 0,930 & 1,5 \\
\hline Pórusbeton falazat & 0,109 & 25 \\
\hline Kőzetgyapot-ragasztó & 0,430 & 1 \\
\hline Kőzetgyapot & 0,0384 & 15 \\
\hline Ragasztó + üvegszövet & 0,430 & 1 \\
\hline Vakolatalapozó & 0,430 & 0,2 \\
\hline Nemesvakolat & 1,280 & 0,3 \\
\hline Zárófödém alatti U-érték [W/m² $\mathrm{K}]$ & 0,155 \\
\hline +Kőzetgyapot-ragasztó & 0,430 & 1 \\
\hline +Kőzetgyapot & 0,0384 & 15 \\
\hline \multicolumn{2}{|l|}{ Zárófödém feletti U-érték [W/m $\left.{ }^{2} \mathrm{~K}\right]$} & 0,097 \\
\hline
\end{tabular}

használt dübelek pontszerű hőátbocsátási tényezője $0,00198 \mathrm{~W} / \mathrm{K}$ [10], és összességében 6\%-kal növeli a kőzetgyapot hővezetési tényezőjét, negatívan befolyásolva ezáltal a homlokzati falak, illetve az alsó zárófödém hővezetési ellenállását.

A szimuláció során a homlokzati külső fal és a zárófödém találkozásánál 7,737 W/m hőáram alakul ki, így a vonalmenti hőhíd értéke 0,062 W/mK. A tűzfal belső oldalára beépített kőzetgyapot lemezek majdnem a felére redukálták a hőáramot a zárófödém belső sarkában, a többlet-hőszigetelés nélkül 0,120 W/mK lenne a $\Psi$ értéke.

\subsection{Alsó zárófödém}

Az alsó zárófödém hőszigetelése $25 \mathrm{~cm}$ kőzetgyapottal történt, amelynek a rétegrendje alapján (3. táblázat) a kapott $U$ érték $0,131 \mathrm{~W} / \mathrm{m}^{2} \mathrm{~K}$.

A termikus burok érdekében a vasbeton gerendák körül is megmaradt a $25 \mathrm{~cm}$ szigetelés (5., 7., 8. ábra). A pillérek és a födém találkozásánál a pontszerű hőhidak redukálása érdekében az oszlop teljes magasságában $5 \mathrm{~cm}$-es kőzetgyapottal lett bevonva, megszüntetve a vasbeton szerkezet külső térrel való találkozását. A homlokzatoknál a konzolos födém úgy volt méretezve és kialakítva, hogy a pórusbeton falazat $5 \mathrm{~cm}$-rel kinnebb helyezkedjen el a vasbeton pillér külső oldalához képest, így a pillér sávjában $20 \mathrm{~cm}$ vastag a hőszigetelés, amely kompenzálja a vasbeton kedvezőtlen hővezetési tényezőjét.

Az alsó gerendás zárófödém és a vasbeton pillérek találkozásánál a hőveszteség túlnyomó többsége az oszlopok irányába távozik, mivel a függőleges tartószerkezet teljes mértékben kültéri
3. táblázat. Az alsó zárófödém hőátbocsátási tényezője

\begin{tabular}{|l|c|c|}
\hline \multicolumn{1}{|c|}{ Rétegsorrend } & $\begin{array}{c}\lambda \\
\text { [W/mK] }\end{array}$ & $\begin{array}{c}\text { Vastagság } \\
\text { [cm] }\end{array}$ \\
\hline Kerámia burkolólap & 2,030 & 1 \\
\hline Ragasztóhabarcs & 0,930 & 1 \\
\hline Aljzatbeton & 0,930 & 5 \\
\hline PE fólia & 0,290 & 0,2 \\
\hline EPS hőszigetelés & 0,042 & 3 \\
\hline Vasbeton födém & 0,930 & 13 \\
\hline Kőzetgyapot-ragasztó & 0,430 & 1 \\
\hline Kőzetgyapot & 0,0384 & 25 \\
\hline Ragasztó + üvegszövet & 0,430 & 1 \\
\hline Vakolatalapozó & 0,430 & 0,2 \\
\hline Nemesvakolat & 1,280 & 0,3 \\
\hline \multicolumn{2}{|c|}{ U-érték [W/m $\left.{ }^{2} \mathrm{~K}\right]$} \\
\hline
\end{tabular}

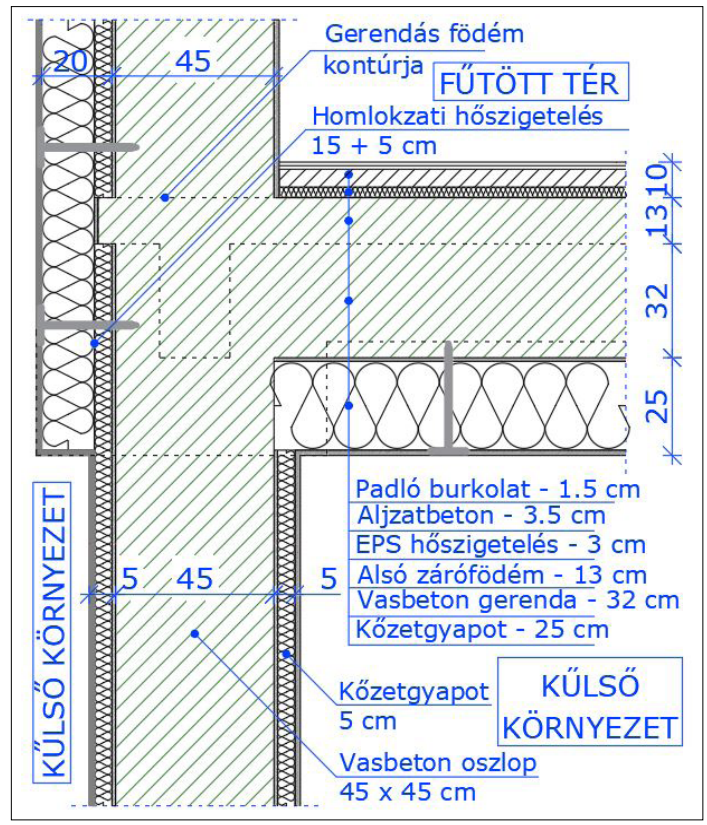

5. ábra. A vasbeton pillér - zárófödém csomópontja

elemnek minősül. A vasbeton pillér $45 \times 45 \mathrm{~cm}$-es keresztmetszetéből, illetve a pozíciójából kifolyólag a tanulmány ezt a csomópontot vonalmenti hőhídnak tekinti, és a $\psi$ értéket a fütött tér belső sarkában határozza meg.

A beton kedvezőtlen hővezetési tényezőjének, illetve a pillér méreteiből származó hőkapacitásának köszönhetően a termikus burok ezen pontján a hőáram eléri a $21,946 \mathrm{~W} / \mathrm{m}$ értéket. A szimuláció során kapott 2 dimenziós hőhíd té- 
nyező értéke $0,665 \mathrm{~W} / \mathrm{mK}$, illetve a vonalmenti hővezetési tényező $0,464 \mathrm{~W} / \mathrm{mK}$ (6. ábra). Tekintettel arra, hogy a zárófödémnél ezek a hőhidak csak három helyen jelennek meg, nem befolyásolják nagy arányokban a rétegtervi $U$ értéket. Sokkal számottevőbb hőveszteség alakulhat ki a födém peremgerendái sávjában.

A köztes gerendának folytonos hőszigetelése minimálisra csökkentette a hőhidakat, a vonalmenti hőátbocsátási tényező 0,017 W/mK (7. ábra). Abban az esetben, amikor a vasbeton gerenda nincs megfelelően hőszigetelve, és csupán $5 \mathrm{~cm}$ vastag kőzetgyapot borítja be az alját, a $\Psi$ értéke eléri a 0,096 W/mK-t, ami hatszorosára növeli a hőáramot a gerenda síkjában.

A zárófödém perem menti gerendája esetén a csomópont geometriájából kifolyólag nagyobb a hőáram, mint a köztes gerendáknál. Habár a termikus burok ebben a zónában is folytonos, illetve a vasbeton gerenda külső oldalán lehetséges volt egy $32,5 \mathrm{~cm}$ vastag hőszigetelő réteget elhelyezni a kapott vonalmenti hőátbocsátási tényező $0,105 \mathrm{~W} / \mathrm{mK}$ (8. ábra). A kedvezőtlen variáns esetén, amikor nem létezik többlet-hőszigetelés, a $\psi$ érték meghaladja a 0,174 W/mK-t.

\subsection{Rétegtervi hőátbocsátási tényezők}

A kéttípusú térelhatároló elem javított hőátbocsátási tényezőjét a kezdeti U érték, illetve a vonalmenti és pontszerű hőátbocsátási tényezők határozzák meg. A 4. táblázatban észrevehető, hogy a padlásfödém nagy alapfelülete a hőhidak mértékének számítását pozitívan befolyásolja, és mivel sikerült minimálisra csökkenteni a hőveszteségeket, a kezdeti U érték 10,6\%-kal növekedett. A zárófödém esetén, ahol viszonylag kis felületen két olyan zóna is létezik, ahol a hőhidak emelkedett értéket vesznek fel, a pontosított hőátbocsátási tényező 45,8\%-kal nőtt.

4. táblázat. A térelhatároló elemek rétegtervi U értékei

\begin{tabular}{|c|c|c|c|c|}
\hline & \multicolumn{2}{|c|}{ Padlásfödém } & \multicolumn{2}{c|}{ Zárófödém } \\
\hline$U\left[\mathrm{~W} / \mathrm{m}^{2} \mathrm{~K}\right]$ & \multicolumn{2}{|c|}{0,150} & \multicolumn{2}{c|}{0,131} \\
\hline$A\left[\mathrm{~m}^{2}\right]$ & \multicolumn{2}{|c|}{946,90} & \multicolumn{2}{|c|}{35,40} \\
\hline \multirow{3}{*}{$\Psi \cdot l[\mathrm{~W} / \mathrm{K}]$} & 0,017 & 42,75 & 0,464 & 1,35 \\
\cline { 2 - 5 } & 0,094 & 121,8 & 0,017 & 3,40 \\
\cline { 2 - 5 } & 0,062 & 31,10 & 0,105 & 13,75 \\
\hline \multirow{3}{*}{$\chi \cdot n[\mathrm{~W} / \mathrm{K}]$} & 0,0314 & 57 & \multicolumn{2}{|c|}{0,00} \\
\cline { 2 - 5 } & 0,0008 & 57 & \multicolumn{2}{|c|}{0,00} \\
\cline { 2 - 5 } & 0,0008 & 97 & \multicolumn{2}{|c|}{0,00} \\
\hline \multirow{2}{*}{$U^{\prime}\left[\mathrm{W} / \mathrm{m}^{2} \mathrm{~K}\right]$} & \multicolumn{2}{|c|}{0,166} & \multicolumn{2}{c|}{0,191} \\
\hline
\end{tabular}

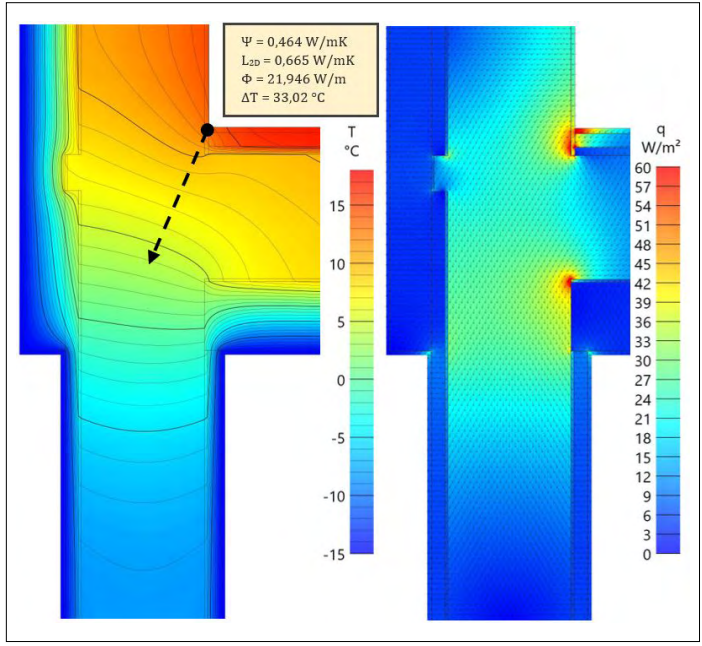

6. ábra. A vasbeton pillér - zárófödém hőmérsékleteloszlása és hőáramsürüsége

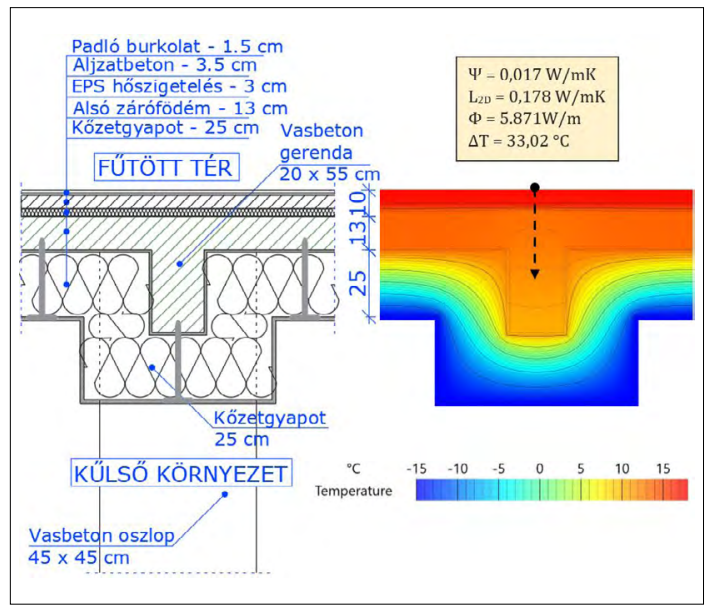

7. ábra. A köztes vasbeton gerenda höszigetelése és $\Psi$ értéke

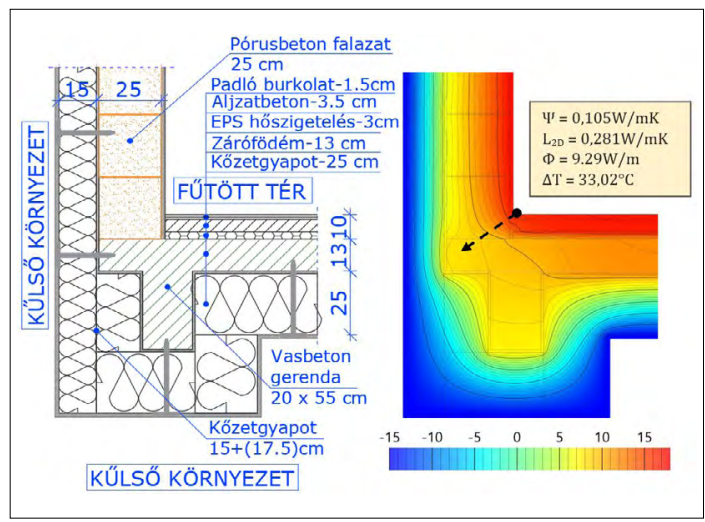

8. ábra. A zárófödém szélső vasbeton gerendája 
A födém hőhidjainak 67\%-át a szélső gerendák alkotják, melyeknél a vonalmenti hőveszteségek csökkentése csak jelentős esztétikai kompromiszszummal valósítható meg a csomópont geometriai formája miatt. A vasbeton pillér és a zárófödém találkozásánál lehetséges a hőhíd kialakulásának visszafogása, ha az oszlopot nem $5 \mathrm{~cm}$, hanem 15 vagy $20 \mathrm{~cm}$ vastag kőzetgyapottal veszi körül. Az első megoldás esetén a vonalmenti hőátbocsátási tényező $0,332 \mathrm{~W} / \mathrm{mK}$-re csökken, a második variánsnál csupán 0,295 W/mK-re esik vissza. A vasbeton pillérek esetében tehát alkalmazható a további $10 \mathrm{~cm}$ vastagságú hőszigetelés, amely során 40 százalékkal csökkenne a hőveszteség ezekben a pontokban.

Összehasonlítva az alkalmazott hőszigetelést a hagyományos szigetelési megoldásokkal (9. ábra), megállapítható, hogy az U’ értéke további 10\%-kal romlana, ha nem lenne figyelembe véve a termikus burok folytonossága, illetve a székoszlopok és a tűzfalak további hőszigetelése. Az így kapott $U$ érték $0,183 \mathrm{~W} / \mathrm{m}^{2} \mathrm{~K}$ majdnem $22 \%$-kal rontana a kezdeti hővezetési ellenálláson.

Az alsó zárófödém esetén a hagyományos hőszigetelési megoldásokat alkalmazva a hőátbocsátási tényező $0,233 \mathrm{~W} / \mathrm{m}^{2} \mathrm{~K}$, további $20 \%$-kal növelve a hőveszteséget, és meghaladva ezáltal a zárófödémnél előírt maximum U értéket, ami 0,20 W/ $\mathrm{m}^{2} \mathrm{~K}$.

\section{Következtetések}

A tanulmányozott padlásfödém székoszlopai és a tűzfalak beburkolása plusz hőszigeteléssel fütetlen térben alkalmazható megoldást jelent a vonalmenti és pontszerű hőhidak csökkentésére a szerkezeti elemeknél, továbbá a menetes szárak által keletkezett pontszerű hőhíd nem befolyásolja számottevően a termikus burok hőátbocsátási tényezőjét.

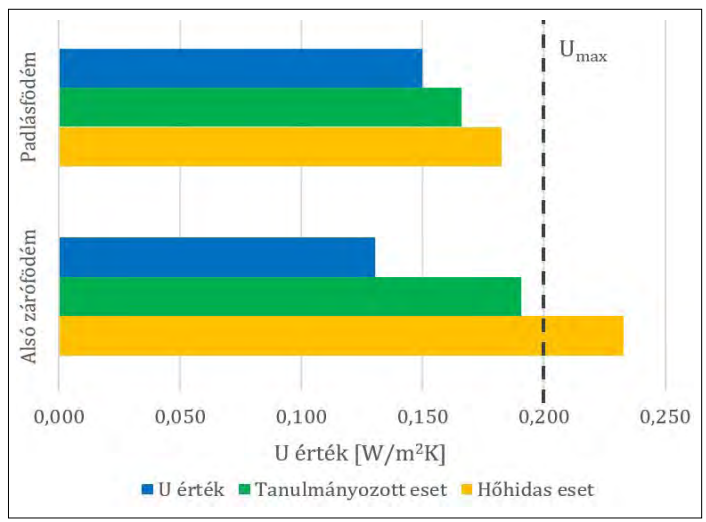

9. ábra. Rétegtervi U értékek összehasonlítása
Az alsó zárófödém esetén a térelhatároló elemek geometriai kialakítása hátrányt jelent a hőhidak csökkentésénél és kisebb felületü épületszerkezeteknél, nagyobb arányban romlik azok hővezetési ellenállása. A vasbeton pillérek hőszigetelési vastagságának növelése viszont kedvezőbben befolyásolhatja a hőveszteségek kialakulását a födémnél.

A tanulmányozott épülethatároló elemeknél megállapítható, hogy a hőveszteségeket akár $20 \%-k a l$ is csökkenteni lehet, ha nagyobb figyelmet kapnak a csomópontok geometriai és hőtechnikai megoldásai. Minimalizálva a hőhidak kialakulását, optimalizálni lehet a hőátbocsátási tényezőket, úgy, hogy ne legyen szükséges megnövelni a hőszigetelés vastagságát a teljes felületen.

\section{Szakirodalmi hivatkozások}

[1] 2018/2002: Az Európai Parlament és Tanács (EU) irányelve az energiahatékonyságról szóló 2012/27 (EU) irányelv módosításáról. 2018.

[2] Az Európai Parlament és a Tanács 2010/31/EU irányelve az épületek energiahatékonyságáról. 2010.

[3] 13/2016: Rendelet az épületek energiahatékonyságáról szóló 372/2005. sz. törvény módosításáról.

[4] Daniel D., Tănasă C., Stoian V., Brata S., Stoian D., Nagy-György T., Floruț S. C.: Passive house design: An efficient solution for residential buildings in Romania. Energy for Sustainable Development. 32. (2016) 99-109. https://doi.org/10.1016/j.esd.2016.03.007

[5] Boros I., Tănasă C., Stoian V., Daniel D.: Thermal studies of specific envelope solutions for an energy efficient building. Key Engineering Materials, 660. (2015) 192-197.

https://doi.org/10.4028/www.scientific.net/ KEM.660.192

[6] Mc001/1-2006: Methodology for calculation of energy performance of building. The building envelope.

[7] EN ISO 10211:2017 - Thermal bridges in building construction - Heat flows and surface temperatures - Detailed calculations

[8] HTflux - Hygric and Thermal Simulation Software (letöltve: 2020. október 20.). https://www.htflux.com/

[9] Passipedia - The Passive House Resource https://passipedia.org/ (letöltve: 2020. október 20.).

[10] Karda Sz., Nagy-György T., Daniel D., Boros I.: Analysis of the thermal behavior of a glass fiber rein-forced polyamide fastener. In: $18^{\text {th }}$ International Technical-Scientific Conference on Modern Technologies for the $3^{\text {rd }}$ Millennium. Oradea, Romania, 2019. 217-222. 